\title{
Clinical application of human $\beta$-defensin and CD14 gene polymorphism in evaluating the status of chronic inflammation
}

Wings TY Loo ${ }^{1,2}$, Lan-jun Bai ${ }^{3}$, Chang-bin Fan ${ }^{4}$, Yuan Yue ${ }^{5}$, Yi-ding Dou ${ }^{6}$, Min Wang ${ }^{5}$, Hao Liang ${ }^{5}$, Mary NB Cheung ${ }^{6,7}$, Louis WC Chow ${ }^{1 *}$, Jin-le Li ${ }^{5}$, Ye Tian', Liu Qing ${ }^{1}$

From Organisation for Oncology and Translational Research (OOTR) 7th Annual Conference Hong Kong. 13-14 May 2011

\begin{abstract}
Background: Periodontitis is a common disease that affects the periodontal tissue supporting the teeth. This disease is attributed to multiple risk factors, including diabetes, cigarette smoking, alcohol, pathogenic microorganisms, genetics and others. Human beta-defensin-1 (hBD-1) is a cationic antimicrobial peptide with cysteine-rich ß-sheets and broad-spectrum antimicrobial activity. CD14 is a protein involved in the detection of bacterial lipopolysaccharide (LPS) and has also been associated with periodontitis. This study investigates the single nucleotide polymorphic (SNP) region, -1654(V38I), of the human beta-defensin-1 (hBD-1) gene as well as the -159 region of the CD14 gene in subjects with chronic periodontitis.

Methods: Blood samples from periodontally healthy subjects and periodontitis patients were obtained. DNA was extracted from the blood and was used to perform restriction digest at the polymorphic G1654A site of DEFB1 with the enzyme Hincll. The polymorphic site 159TT of CD14 was digested with the enzyme Avall. Enzyme-linked immunosorbent assay (ELISA) was performed on soluble samples to determine the protein expressions.

Results: The control and patient groups expressed 35\% and 38\% 1654 A/A genotype of DEFB1, respectively. The A allele frequency of the control group was $40 \%$, while the patient blood group was $54 \%$. The mean hBD-1 protein levels of the control and patient samples were $102.83 \mathrm{pg} / \mathrm{mL}$ and $252.09 \mathrm{pg} / \mathrm{mL}$, respectively. The genotype distribution of CD14 in healthy subjects was $16 \%$ for $C / C, 26 \%$ for $T / T$ and $58 \%$ for $C / T$. The genotype frequencies of CD14 in periodontitis patients were 10\% for C/C, 43\% for $\mathrm{T} / \mathrm{T}$ and $47 \%$ for $\mathrm{C} / \mathrm{T}$. The CD14 protein expression determined by ELISA showed a mean protein level of the control samples at $76.28 \mathrm{ng} / \mathrm{mL}$ and the patient blood samples at $179.27 \mathrm{ng} / \mathrm{mL}$ with a $p$ value of 0.001 .

Our study demonstrated that patients suffering from chronic periodontitis present more commonly with the 1654A/A genotype on the DEFB1 gene and the 159T/T genotype on the CD14 gene.

Conclusions: This study purely investigated the association between periodontitis and one polymorphic site on both DEFB1 and CD14 gene, with the purpose of expanding knowledge for the future development in diagnostic markers or therapeutic interventions to combat this disease.
\end{abstract}

\footnotetext{
* Correspondence: Iwcchow@unimed.hk

'UNIMED Medical Institute, Hong Kong SAR

Full list of author information is available at the end of the article
} 


\section{Background}

Periodontitis is a chronic infectious disease[1] involving the degradation and destruction of periodontal supporting tissue of the teeth[2]. This disease is highly prevalent and can affect up to $90 \%$ of the worldwide population [3]. The causes and risk factors include oral microorganisms such as Porphyromonas gingivalis ( $P$. gingivalis) [4], genetic factors (Nares, 2003), acquired environmental factors like tobacco smoking [5], uncontrolled diabetes [6], stress [7], impaired host response [3,8], alcohol use, HIV and AIDS, malnutrition, and osteoporosis[10]. Of the mentioned factors, genetic polymorphisms have attracted much attention, and a number of studies have been conducted in different ethnic populations worldwide to gain additional knowledge.

In recent years, a number of genetic polymorphisms and their association with periodontal diseases have been studied[11], which include interleukin (IL) -1 [12], IL-1 $\alpha$ [13], IL-1 $\beta$ [14] IL-10 (Sumer et al., 2007)[15], IL-17 [16], matrix metalloproteinases [17] and others. Human $\beta$ defensins (hBDs) are a group of low molecular weight (3 to $5 \mathrm{kDa}$ ) cationic antimicrobial peptides with cysteinerich $ß$-sheets. Defensins possess broad-spectrum antimicrobial activity that kill microbes by inducing physical holes in the membrane (Li et al., 2007)[18]. They contribute to host innate immunity by disrupting the membrane integrity of a broad spectrum of microorganisms [19]. These peptides, encoded by the DEFB genes, are present in three main gene clusters located on chromosome 8p2234 [20]. At least four types of defensins (hBD-1 to hBD-4) have been characterized in humans. hBD-1 was first isolated from the hemofiltrate of patients with end stage kidney disease undergoing dialysis, and renal epithelia were found as the major source [21]. Human $\beta$ defensins, namely hBD-1 and hBD-2, have been recently identified from plasma and various epithelial tissues [21,22]. Although $\alpha$ and $\beta$ defensins are encoded by different genes, these genes share a common evolutionary origin [23]. hBD-2 expression is induced by stimuli such as bacteria and proinflammatory cytokine TNF- $\alpha$, thereby evoking the important functions of hBD-2 in acute inflammation [23].

hBD-1 (encoded by DEFB1) and hBD-3 (encoded by $D E F B 103)$ are constitutively expressed at low levels in the skin [24]. hBD-1 is not normally expressed in the circulation. hBD-2 (encoded by DEFB4) is not expressed in normal skin but is highly expressed in inflammatory tissues. hBD-2 is absent or at low levels in normal epithelia. Serum hBD-2 levels in healthy individuals are very low (less than $1 \mathrm{ng}$ per $\mathrm{ml}$ ) [25]; conversely, the levels are highly inducible and expressed locally or systemically on inflammatory stimulation [26]. The localizations of hBD-2 expression include nasal [27] and oral mucosa [28], gingival epithelia [29], human airway [30], nasolacrimal duct [31], and ocular surface epithelium [32], as well as intestinal epithelium [33] in response to infection and inflammation. The constituent protein, $\mathrm{hBD}-1$, is not normally expressed in the circulation. However, hBD-2 is inducible and expressed locally or systemically on stimulation [26].

Genetic polymorphisms of hBD-1 and their associations with periodontitis have been investigated at SNP sites -692 and -44 , respectively [34]. The conducted studies concluded that associations do not exist for hBD-1 polymorphisms at these SNP sites and periodontitis. In contrast, SNP site -1654 of DEFB1 has been demonstrated to have a positive correlation with common diseases such as chronic obstructive pulmonary disease [35] and atopic dermatitis [36]. However, its association with periodontitis has not been studied.

CD14 is a $55-\mathrm{kDa}$ glycosyl phosphatidylinositolanchored glycoprotein expressed on the surface of white cells [37]. As a LPS receptor it can bind to the LPS, leading to nuclear factor- $\kappa \mathrm{B}$ activation and cytokine expression mediated by the TLR4/MD2 complex [38]. CD14 exists in two forms: either anchored to a cell membrane by a glycosylphosphatidylinositol tail (mCD14), or in soluble form (sCD14). sCD14 is produced by enzymatically cleaved membrane $C D 14$, mediated mainly by phospholipase C, and via secretion of CD14 [39]. Usually, $C D 14$ binds to LPS in the presence of lipopolysaccharide-binding protein. Subsequently, a series of reactions take place and eventually trigger intracellular signalling, causing the production of pro-inflammatory cytokines. Its concentration in serum has been found to increase in several clinical pathologies, such as periodontitis [40], rheumatoid arthritis [41], systemic lupus erythematosus [42] and tuberculosis [43]. A SNP is found at position -159 in the $C D 14$ promoter, where a $\mathrm{C}$ to $\mathrm{T}$ transition occurs [59]. Previous studies have shown an association of the CD14-159 TT genotype with chronic periodontitis [40], myocardial infarction [44] and pulmonary tuberculosis [45].

Our recent in vitro study in the reconstituted human gingival epithelium model shows that in addition to TLR2 and TLR4, CD14 may also be involved in the regulation of hBD-2 expression by $P$. gingivalis LPS [46]. Lipopolysaccharide, interleukin-1 $\beta$ (IL-1 $\beta$ ), and tumor necrosis factor-a (TNF- $\alpha$ ) are known as highly specific $\beta$-defensin inducers [19].

Considering the association of CD14 genetic polymorphisms with the severity of chronic periodontitis [40], the present study investigated for the first time the potential association of both $\mathrm{hBD}$ and $C D 14$ polymorphisms and their serum levels with chronic periodontitis in Chinese subjects. 


\section{Methods}

\section{Selection of subjects}

108 systemically healthy, non-smoking Chinese adults (39 females and 69 males, aged 18 to 60) were randomly selected from the voluntary blood donors at Hong Kong Red Cross between September 2004 and March 2007. After the blood samples of these healthy volunteers were collected, they were scheduled for oral examinations at Keenlink Dental Clinic, Hong Kong, where they were determined to be clinically healthy or have gingivitis, without furcation involvement or generalized gingival recession. All subjects who were determined to be free of oral soft tissue abnormalities or severe dental caries were allocated to the control group.

44 Chinese subjects (18 females and 26 males, aged 18 to 74 years) with moderate to advanced chronic periodontitis were recruited from West China Hospital of Stomatology, Sichuan University. The diagnosis of chronic periodontitis was made following the criteria defined by the American Academy of Periodontology in 1999 [49]. The subject data are presented in Table 1. Both groups of the subjects did not have more than 4 teeth missing in the dental ridge. They did not have systemic diseases (such as diabetes, uncontrolled hypertension), and they did have a smoking history.

The sample size of this study was determined based on the reports of Machin and Lemeshow. In the report, the sample size was determined based on 0.05 level of significance for two arms to achieve $90 \%$ power $[47,48]$.

The study protocols were approved by the Ethics Committee, Faculty of Medicine, The University of Hong Kong and Sichuan University, PRC. Informed consent was obtained from all subjects.

\section{Sampling}

Peripheral blood samples were collected by direct venipuncture from the arm vein of each subject: $20 \mathrm{ml}$ in lithium heparin tubes and $10 \mathrm{ml}$ in clot blood tubes (BD Vacutainer, NJ USA), respectively. The samples were certrifuged for $10 \mathrm{~min}$ at 1,500 rotations per minute (rpm), and serum and plasma was then collected for enzyme-linked immunosorbent assay (ELISA) analysis. The remaining cellular components were transferred to a $50 \mathrm{ml}$ centrifuge tube with an addition of red blood cell lysis buffer up to $45 \mathrm{ml}$. The mixture in the tube was inverted several times and then centrifuged for $10 \mathrm{~min}$ at $1,500 \mathrm{rpm}$. The supernatants were discarded, and the remaining components were washed with $0.9 \%$ PBS used for DNA extraction.

\section{Extraction of DNA}

Genomic DNA was extracted from each blood sample using the QIAamp DNA Blood Mini Kit (QIAGEN, MD, USA). The DNA concentration was estimated by measurement of $\mathrm{OD}_{260}$. The extracted DNA was labelled and stored at $-80^{\circ} \mathrm{C}$ until further analysis.

\section{Polymerase chain reaction (PCR), restriction enzyme cleavage and gel electrophoresis}

The 111 bp exon region consisting of the G1654A SNP region of $D E F B 1$ was amplified using the following primers: forward, 5'-CAAGCCATGAGTCTGAAGTGT-3'; and reverse, 5'-TCAACAGTGGAGGGCAATGT-3' according to a previous study[35]. A PCR kit (Promega Corporation, U.S.A) was used according to the manufacturer's instructions. The kit consisted of a PCR Master Mix (50 units/ml Taq DNA Polymerase) supplied in a proprietary reaction buffer ( $\mathrm{pH} 8.5), 400 \mu \mathrm{M}$ each of dATP, dGTP, dCTP, dTTP, and $3 \mathrm{mM}$ of $\mathrm{MgCl}_{2}$, and nuclease free water. All procedures were carried out in a sterile and stable environment to prevent external contamination. PCR was undertaken in a thermal cycler (MJ, U.S.A.) with a mixture containing 20 units of nuclease-free water, 25 units of Master Mix, 0.5 units of each primer and 3 units of extracted DNA sample. The cycling conditions programmed were denaturation at $94^{\circ} \mathrm{C}$ for $5 \mathrm{~min}$, followed by 30 cycles at $94^{\circ} \mathrm{C}$ for $30 \mathrm{sec}$, $30 \mathrm{sec}$ at $56^{\circ} \mathrm{C}$, extension at $72^{\circ} \mathrm{C}$ for $1 \mathrm{~min}$, with a final extension at $72^{\circ} \mathrm{C}$ for $5 \mathrm{~min}$. The products from the thermal cycling were stored at $-80^{\circ} \mathrm{C}$ until restriction enzyme digestion [35].

Table 1 Demographic and clinical data (Mean \pm SD; \% of Subjects or Sites)

\begin{tabular}{ccc}
\hline Parameters & Control subjects (N = 108) & Periodontitis patients $(\mathbf{N}=\mathbf{4 4})$ \\
\hline Age (years) & $42.9 \pm 9.7$ & $49.3 \pm 13.6$ \\
Age range (years) & $18-60$ & $18-74$ \\
Male/female & $64 / 36$ & $59 / 41$ \\
PD (mm) & $2.7 \pm 1.2$ & $6.1 \pm 2.7^{*}$ \\
Sites\% with BOP & $40.3 \pm 9.5$ & $78.2 \pm 19.8^{*}$ \\
Sites\% with gingival recession & $1 \pm 1.2$ & $38.9 \pm 25.9^{*}$ \\
Sites\% with calculus & $34.1 \pm 13.6$ & $63.0 \pm 25.8$ \\
Clinical Attachment Loss (mm) & 0.0 & $6.2 \pm 2.9$ \\
\hline
\end{tabular}

Significant difference from the control, ${ }^{*} p<0.05$ 
The $111 \mathrm{bp}$ of $D E F B 1$ fragment generated from the PCR procedure was digested using HincII restriction enzyme (Fermentas Life Sciences, USA). A $10 \mu \mathrm{l}$ aliquot of the PCR product was mixed with 5 units of HincII, $10 \mu \mathrm{l}$ of nuclease free water and $1 \mu \mathrm{l}$ of restriction enzyme buffer. The entire mixture was incubated at $37^{\circ} \mathrm{C}$ for 2 hours. All digestion reagents were kept on ice before incubation.

The electrophoresis was performed with $5 \mu \mathrm{l}$ of digestion product and $1 \mu \mathrm{l}$ of Ready-Load $1 \mathrm{~Kb}$ DNA Ladder (Invitrogen, Spain) which were loaded onto a $4 \%$ agarose gel (Invitrogen, Spain), and the gel was visualized with ethidium bromide [35].

The analysis of -159 polymorphism of $C D 14$ was performed following a previous protocol [50]. The CD14 gene promoter was amplified by a PCR fragment of about 500 base pairs of the following primers: forward, 5'-GTGCCAACAGATGAGGTTCAC-3'; and reverse, 5'GCCTCTGACAGTTTATGTAATC-3'. PCR was performed with 250 ng DNA in Master Mix (Promega, WI, USA), $12.5 \mu \mathrm{l}$ of each pairs of primers ( $15 \mathrm{pmol})$. The PCR conditions were denaturation at $94^{\circ} \mathrm{C}$ for $5 \mathrm{~min}$, then 30 cycles at $94^{\circ} \mathrm{C}$ for $30 \mathrm{sec}, 57^{\circ} \mathrm{C}$ for $30 \mathrm{sec}$, extension at $72^{\circ} \mathrm{C}$ for $1 \mathrm{~min}$, and followed by a final extension at $72^{\circ} \mathrm{C}$ for $5 \mathrm{~min}$. The products were stored at $-80^{\circ} \mathrm{C}$ until restriction enzyme digestion. The PCR products was then digested by AvaII (Fermentas Life Sciences, USA) at $37^{\circ} \mathrm{C}$ for $16 \mathrm{~h}$ and separated in a $2.5 \%$ agarose gel. The gel underwent electrophoresis at 100 volts, 100 milliAmperes for $30 \mathrm{~min}$. Visualization was performed by means of a Dolphin-DOC ultraviolet illuminator (Wealtec, South Africa).

\section{Assay of hBD-2 and CD14 by ELISA}

The supernatant of the blood samples were used for hBD2 and CD14 assays (ELISA kits from Phoenix Pharmaceuticals Inc, USA and DIACLONE, Besançon, France, respectively), following the manufacturer's instructions. $100 \mu \mathrm{l}$ of serum samples were pipetted into a 96-well microplate for assay of hBD-2 and CD14, respectively. The microplates were incubated at $350 \mathrm{rpm}$ for 2 hours and washed with washing buffer three times. The wells were then dried and $200 \mu \mathrm{L}$ of substrate tetramethylbenizidine was added into each well for $20 \mathrm{~min}$ at room temperature. The plates were then read at $450 \mathrm{~nm}$ wavelength using Universal Microplate Reader (Sunrise, TECAN, Austria). The levels of hBD-2 and CD14 were determined by comparison with the standard curve generated from the standards supplied by the manufacture. Each sample was analysed in triplicates. The levels of hBD-2 and CD14 were presented as $\mathrm{pg} / \mathrm{ml}$ and $\mathrm{ng} / \mathrm{ml}$, respectively.

\section{Statistical analysis}

The detection frequency and genotype distribution of $D E F B 1$ and $C D 14$ polymorphisms in the patient and control groups was compared by the Chi-square test. The relevant odds ratios between the groups were analyzed. The difference in serum levels of hBD-2 and CD14 between the groups were evaluated with an independent t-test. A $p$-value of 0.05 or less was regarded as statistically significant. Statistical analysis was performed using SPSS 15.0 for Windows (SPSS Inc., Chicago, IL, U.S.A.).

\section{Results}

Table 1 details the clinical results of the periodontitis patient and the healthy control groups. The periodontitis patient group showed significantly greater means than the healthy control group $(p<0.05)$ for the following clinical results: pocket depth (PD): $6.1 \pm 2.7 \mathrm{~mm}$ vs. $2.7 \pm$ $1.2 \mathrm{~mm}$; Clinical Attachment Loss (CAL): $6.2 \pm 2.9 \mathrm{~mm}$ vs. 0 ; percentage of sites with bleeding on probing (BOP): $78.2 \pm 19.8 \%$ vs. $40.3 \pm 9.5 \%$ and gingival recession: 38.9 $\pm 25.9 \%$ vs. $1 \pm 1.2 \%$. There was no significant difference found in the age and gender ratio between the groups.

The blood count of the control subjects and periodontitis patients are presented in Table 2. The results were within the normal range, although the patient group showed a relatively higher count and percentage of lymphocytes and a relatively lower count and percentage of neutrophils $(p<0.05)$ compared to the healthy control group.

Table 2 Blood count (Mean \pm SD) of the control subjects and periodontitis patients

\begin{tabular}{|c|c|c|c|c|}
\hline Parameters & Control subjects $(\mathrm{N}=108)$ & Periodontitis patients $(\mathrm{N}=44)$ & Normal range & Unit \\
\hline White blood cell & $5.03( \pm 1.25)$ & $3.96( \pm 1.02)$ & $4.00-11.00$ & $10^{9} / \mathrm{L}$ \\
\hline Red blood cell & $5.29( \pm 0.11)$ & $4.25( \pm 0.10)$ & $3.8-6.0$ & $10^{12} / \mathrm{L}$ \\
\hline Hemoglobin & $15.9( \pm 0.47)$ & $12.5( \pm 0.43)$ & $11.5-16.5$ & $\mathrm{~g} / \mathrm{dl}$ \\
\hline Platelet & $256( \pm 25.08)$ & $241( \pm 23.31)$ & $150-400$ & $10^{9} / \mathrm{L}$ \\
\hline Neutrophil & $3.67( \pm 1.02)$ & $* 1.68( \pm 0.71)$ & $2.0-7.5$ & $10^{9} / \mathrm{L}$ \\
\hline Lymphocyte & $1.29( \pm 0.58)$ & $* 1.42( \pm 0.26)$ & $1.30-3.5$ & $10^{9} / \mathrm{L}$ \\
\hline Monocyte & $0.44( \pm 0.17)$ & $0.18( \pm 0.11)$ & $0.2-0.7$ & $10^{9} / \mathrm{L}$ \\
\hline Eosinophil & $0.11( \pm 0.55)$ & $0.06( \pm 0.02)$ & $0.0-0.5$ & $10^{9} / \mathrm{L}$ \\
\hline Basophils & $0.02( \pm 0.02)$ & $0.02( \pm 0.01)$ & $0.0-0.1$ & $10^{9} / \mathrm{L}$ \\
\hline
\end{tabular}

Significant difference from the control, ${ }^{*} p<0.05$ 
The DNA sequence of DEFB1 and CD14 demonstrating where SNPs occur and restriction sites are shown in Figures 1, 2 and 3. For DEFB1, homozygous G/G alleles

\section{$\underline{\text { A/A genotype }}$<smiles>C1CC1</smiles>

AATTCAAGGCACCTGTTACA

TTAAGTTCCGAGGACAATGT

\section{G/G genotype}

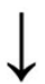

\section{AATTCAAGGCGCCTGTTACA}

TTAAGTTCCGGGGACAATGT<smiles>CCCCC</smiles>

\section{A/G genotype}

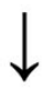

\section{AATTCAAGGCACCTGTTACA}

TTAAGTTCCGGCCTGTTACA

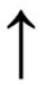

Figure 1 The arrows show the Hincll restriction enzyme digestion at 111 bp position of DEFB1 DNA polymorphism representing A/A, G/G and $\mathrm{A} / \mathrm{G}$ genotypes.

\section{$\underline{\text { T/T genotype }}$}

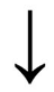

CTGGACGATG

GACCTGCTTC<smiles>CCCC</smiles>

$\underline{\text { C/C genotype }}$

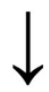

CTGGACGACG

GACCTGCTCC

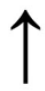

\section{C/T genotype}<smiles>C1CC1</smiles>

CTGGACGACG

GACCTGCTTC

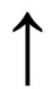

Figure 2 The arrows show the Avall restriction enzyme digestion at -159 bp promoter region of CD14 DNA polymorphism representing $\mathrm{T} / \mathrm{T}, \mathrm{C} / \mathrm{C}$ and $\mathrm{T} / \mathrm{C}$ genotypes.

were represented by a DNA band with a size of $111 \mathrm{bp}$, and the homozygous $\mathrm{A} / \mathrm{A}$ alleles were represented by DNA bands with sizes 93 and 18 bp. Heterozygotes 
displayed a combination of both alleles (111, 93, and 18 bp).

Homozygous $\mathrm{C} / \mathrm{C}$ alleles of $C D 14$ were represented by a DNA band with a size of $497 \mathrm{bp}$, and the homozygous $\mathrm{T} / \mathrm{T}$ alleles were represented by DNA bands with sizes of 353 and $114 \mathrm{bp}$. Heterozygotes $\mathrm{C} / \mathrm{T}$ displayed a combination of the alleles (497, 353 and $144 \mathrm{bp}$ ). Overall, significant difference was found in the distribution of DEFB1 and $C D 14$ genotypes between the groups (Table 3 ). For $D E F B 1$, the detection frequency of $\mathrm{G}$ allele was significantly lower in the patient group (26\%) than in the controls $(59 \%)(p<0.001)$. The subjects with the $\mathrm{G}$ allele are four-folded at lower risk for moderate to severe chronic periodontitis $(p<0.001, \mathrm{OR}=4.111$ with $95 \%$ CI $2.378-$ 7.107). The genotype of $\mathrm{G} / \mathrm{G}$ was significantly lower in the patient group (20\%) than the healthy controls $(54 \%)(p<$ $0.001)$. Individuals with the $\mathrm{G} / \mathrm{G}$ genotype are at approximately four times lower risk for moderate to severe periodontitis than people with A/A and G/A genotypes ( $p<$ 0.001 , OR $=4.511$ with $95 \%$ CI $1.988-10.288$ ).

For $C D 14$, the genotype of $\mathrm{T} / \mathrm{T}$ was significantly higher in the patient group (43\%) than the control group $(26 \%)(p<0.05)$. Individuals with the $\mathrm{T} / \mathrm{T}$ genotype are at twice a greater risk to develop moderate to severe periodontitis than people with $\mathrm{C} / \mathrm{C}$ and $\mathrm{C} / \mathrm{T}$ genotypes $(p<0.05$, OR $=2.171,95 \%$ CI $1.041-4.531)$.

The serum levels of hBD-2 in the patient group were significantly higher than the levels of healthy controls $(p$ $<0.01$ ) (Figure 4). Similar results were found between the subjects with the same genotypes from the control and patient groups. There was no significant difference found in the serum levels of hBD-2 within the control and patient groups who presented with different DEFB1 genotypes (Figures 5 and 6).

The serum levels of CD14 in the patient group were significantly higher than those in the controls $(p<0.01)$ (Figure 7). Similar results were found between the subjects with the same genotypes from the control and patient groups. Within the patient group, the subjects with T/T genotype exhibited higher levels of CD14 than subjects with $\mathrm{C} / \mathrm{C}$ or $\mathrm{C} / \mathrm{T}$ genotypes $(p<0.05)$, while no significant difference was found in the control subjects who presented with different $C D 14$ genotypes (Figures 8 and 9).

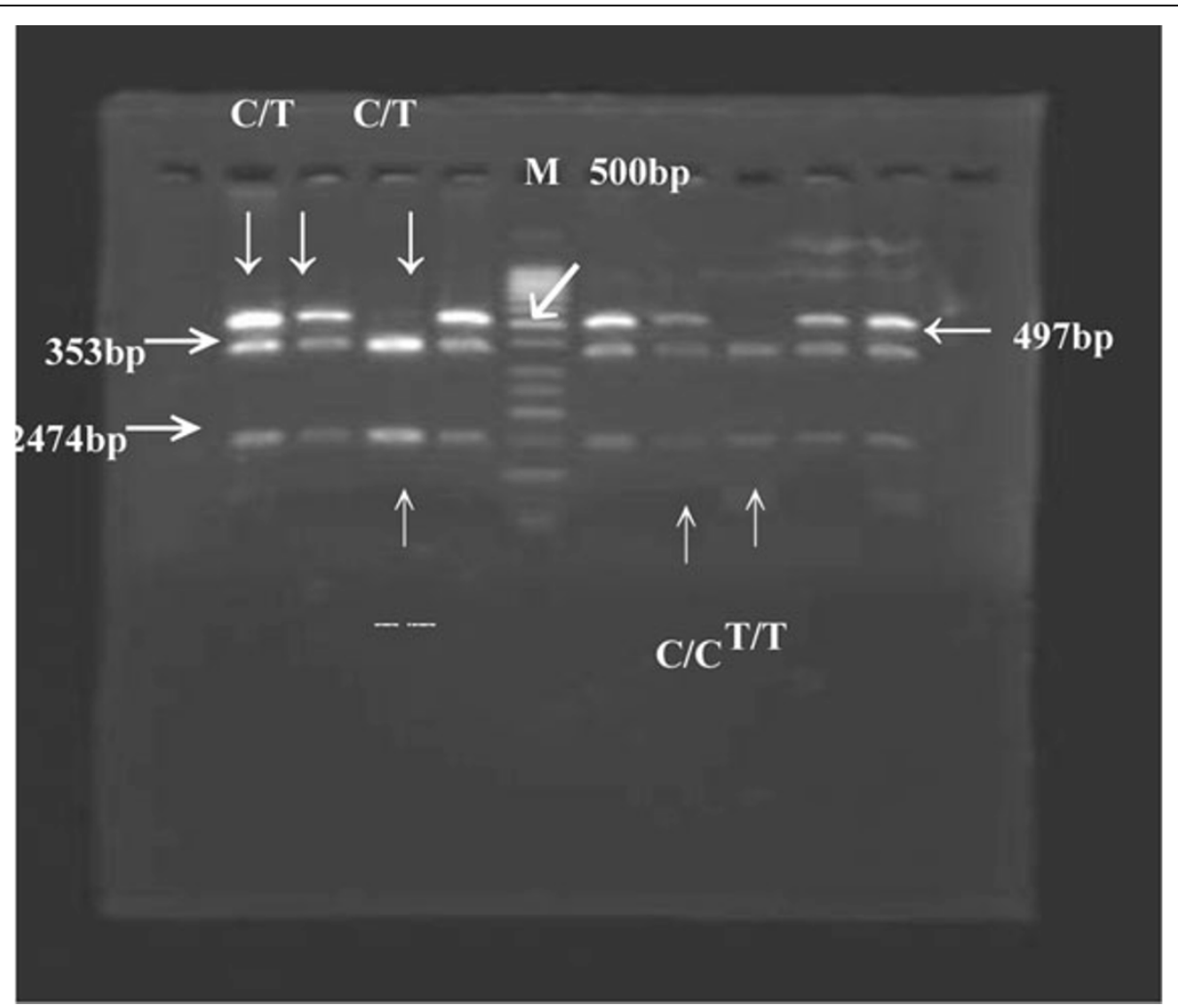

Figure 3 The DNA polymorphism of CD14 at position -159 digested with restriction enzyme Avall. The homozygous C/C alleles were represented by a DNA band with a size of 497 bp (1 band, no cut); homozygous T/T alleles were represented by DNA bands with sizes 353 bp and 144 bp (2 bands), whereas heterozygotes displayed a combination of C/T alleles (3 bands: 497 bp, 353 bp and 144 bp). M represented the DNA marker. 
Table 3 Genotype and allele distribution of DEFB1 and CD14 in control subjects and periodontitis patients

\begin{tabular}{|c|c|c|c|c|c|c|c|c|c|}
\hline \multirow[t]{2}{*}{ Genotypes } & \multirow[t]{2}{*}{$\begin{array}{l}\text { CP Patients } \\
n=44(\%)\end{array}$} & \multirow[t]{2}{*}{$\begin{array}{c}\text { Healthy subjects } \\
n=108(\%)\end{array}$} & \multicolumn{2}{|c|}{$\begin{array}{c}\mathrm{CP} \text { versus Healthy } \\
\text { subjects }\end{array}$} & \multirow[t]{2}{*}{ Alleles } & \multirow[t]{2}{*}{$\begin{array}{l}\text { CP patient } \\
n=88(\%)\end{array}$} & \multirow[t]{2}{*}{$\begin{array}{c}\text { Healthy subjects } \\
n=216(\%)\end{array}$} & \multicolumn{2}{|c|}{$\begin{array}{l}C P \text { versus Healthy } \\
\text { subjects }\end{array}$} \\
\hline & & & OR $(95 \% \mathrm{Cl})$ & $p$ values & & & & OR $(95 \% \mathrm{Cl})$ & $p$ values \\
\hline \multicolumn{10}{|l|}{ DEFB1 } \\
\hline $\mathrm{A} / \mathrm{A}$ & $30(69)$ & $38(35)$ & $\begin{array}{c}3.9474(1.8697- \\
8.3339)\end{array}$ & $<0.0002^{*}$ & A & $65(74)$ & $88(41)$ & $\begin{array}{c}4.1107(2.3775- \\
7.1073)\end{array}$ & $<0.0001^{*}$ \\
\hline $\mathrm{G} / \mathrm{G}$ & $9(20)$ & $58(54)$ & & & G & $23(26)$ & $128(59)$ & & \\
\hline $\mathrm{G} / \mathrm{A}$ & $5(11)$ & $12(11)$ & & & & & & & \\
\hline \multicolumn{10}{|l|}{ CD14 } \\
\hline $\mathrm{T} / \mathrm{T}$ & $19(43)$ & $28(26)$ & $\begin{array}{c}2.1714(1.0406- \\
4.5311)\end{array}$ & $<0.0368^{*}$ & $\mathbf{T}$ & $59(67)$ & $119(55)$ & $\begin{array}{c}1.6584(0.9868- \\
2.7869)\end{array}$ & $<0.05501$ \\
\hline $\mathrm{C} / \mathrm{C}$ & $4(10)$ & $17(16)$ & & & C & 29 (33) & $97(45)$ & & \\
\hline $\mathrm{C} / \mathrm{T}$ & $21(47)$ & $63(58)$ & & & & & & & \\
\hline
\end{tabular}

DEFB1: $\mathrm{G} / \mathrm{G}+\mathrm{G} / \mathrm{A}$ versus $\mathrm{A} / \mathrm{A} ; \mathrm{CD} 14: \mathrm{C} / \mathrm{C}+\mathrm{C} / \mathrm{T}$ versus $\mathrm{T} / \mathrm{T}$; $\mathrm{OR}$, odds ratio; $\mathrm{Cl}$, confidence interval

\section{Discussion}

hBD-1 is a cysteine-rich, cationic antimicrobial peptide with broad-spectrum antimicrobial activity [19]. Thus, rationally, alterations due to genetic polymorphisms at SNP sites may be associated with asthma, HIV-1 in pregnant women and their children, as well as oral Candida carriage [51-53]. The association between DEFB1 gene polymorphism and periodontitis could not be established in previous studies [34]. The present study, however, demonstrated that the DEFB1 SNP at genomic position -1654 , which leads to a $G$ to A substitution and a valine to isoleucine substitution at polypeptide position [35], was present more frequently in patients with moderate to severe chronic periodontitis than the periodontally healthy group. The A/A genotype is mostly presented in the group of chronic periodontitis patients, while the G/G genotype was exhibited in the control group. It has been suggested that the genotypic makeup should be constant in an individual, and any difference in polymorphic status of the genes may arise only in circulation of the body [54].

The results of hBD-2 in serum expression support our findings from the digests. The periodontally healthy control group presented with a lower level (102.83 pg/ $\mathrm{ml}$ ) of hBD-2 than the patient group $(252.09 \mathrm{pg} / \mathrm{ml})$. The results suggest that subjects with the 1654AA genotype may tend to exhibit a higher serum level of hBD-2 in response to periodontal infection. Further investigations would be required to confirm this hypothesis.

Schaefer et al's findings provide evidence for a significant association of the rare A allele of the DEFB1 variant with an increased risk for periodontal diseases [55]. This association was independent of the periodontitisspecific covariates: smoking, diabetes and gender. The

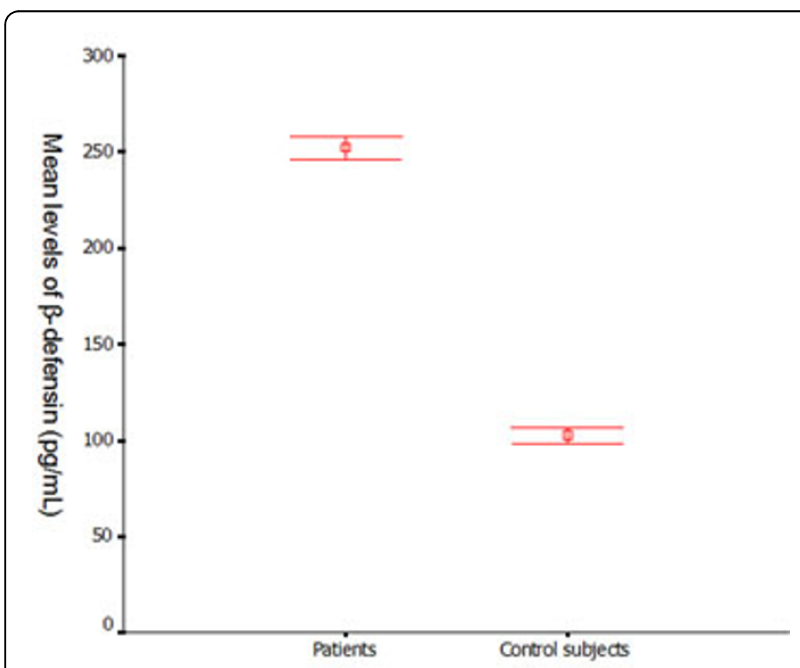

Figure 4 Serum levels of hBD-2 (Mean \pm SD) in control subjects and periodontitis patients were measured by ELISA.

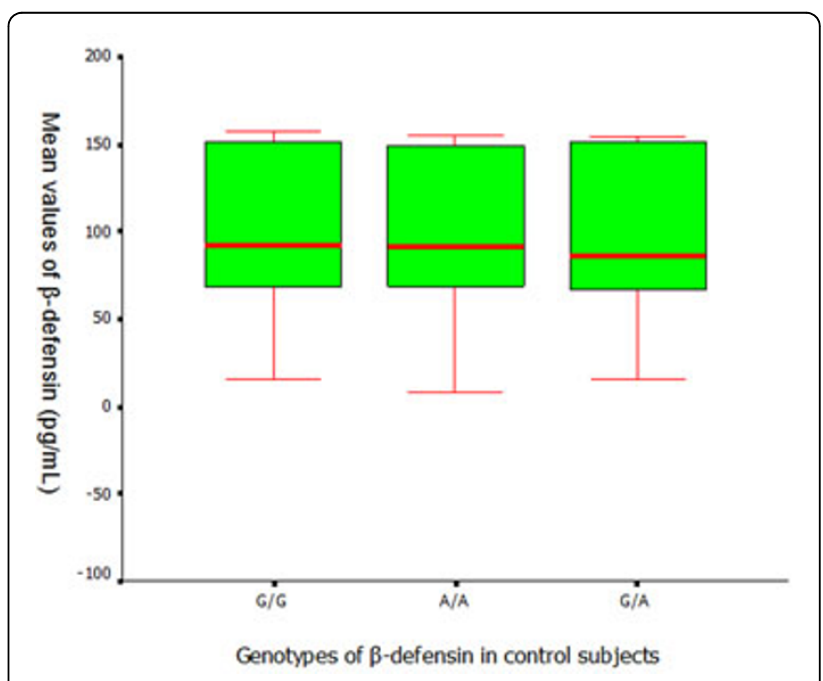

Figure 5 ELISA assay of hBD-2 (Mean \pm SD) applied to measure the serum levels in control subjects with different $D E F B 1$ genotypes. 


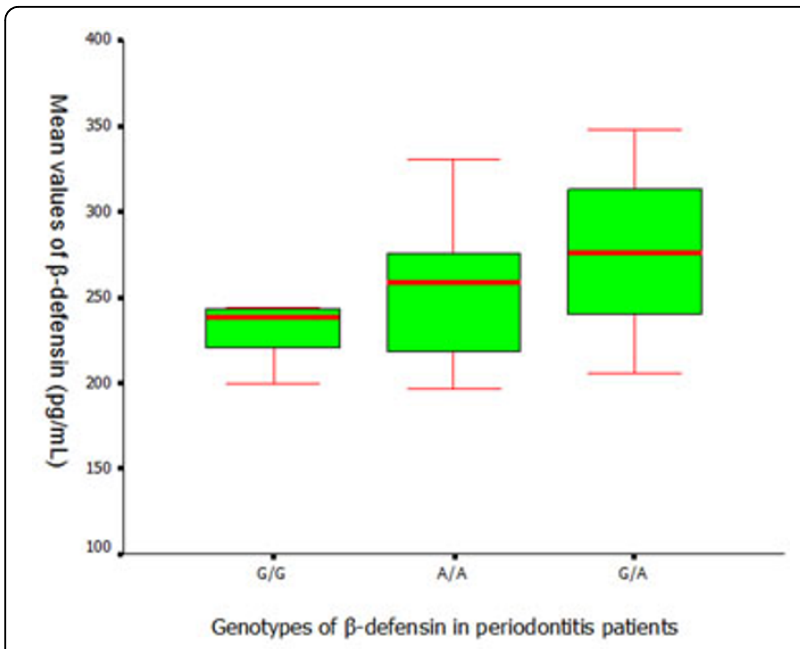

Figure 6 ELISA assay of hBD-2 (Mean \pm SD) applied to measure the serum levels in periodontitis patients with different DEFB1 genotypes.

robustness of the data was further supported by a separate analysis of the two parodontopathic distinct forms: chronic and aggressive periodontitis [55]. Their results were comparable to our findings with a higher rate of $\mathrm{A}$ genotype and $\mathrm{A}$ allele and a lower rate of $\mathrm{G}$ genotype and $\mathrm{G}$ allele. The DEFB1 indicated that the G-A nucleotide transition could influence the putative binding site of its proteins [55].

The CD14-159 $\mathrm{C}>\mathrm{T}$ polymorphism, a SNP at position -159 in the promoter region of the gene encoding this pattern recognition receptor, is associated with elevated plasma/serum concentrations of soluble CD14, an increased risk for myocardial infarction and a decreased risk for allergies and asthma [56].

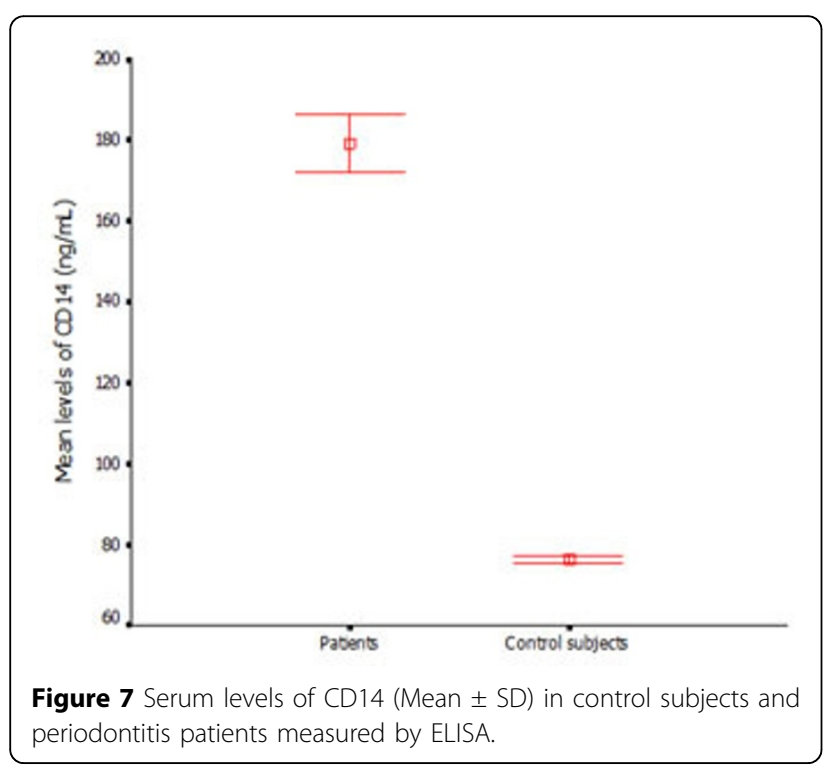

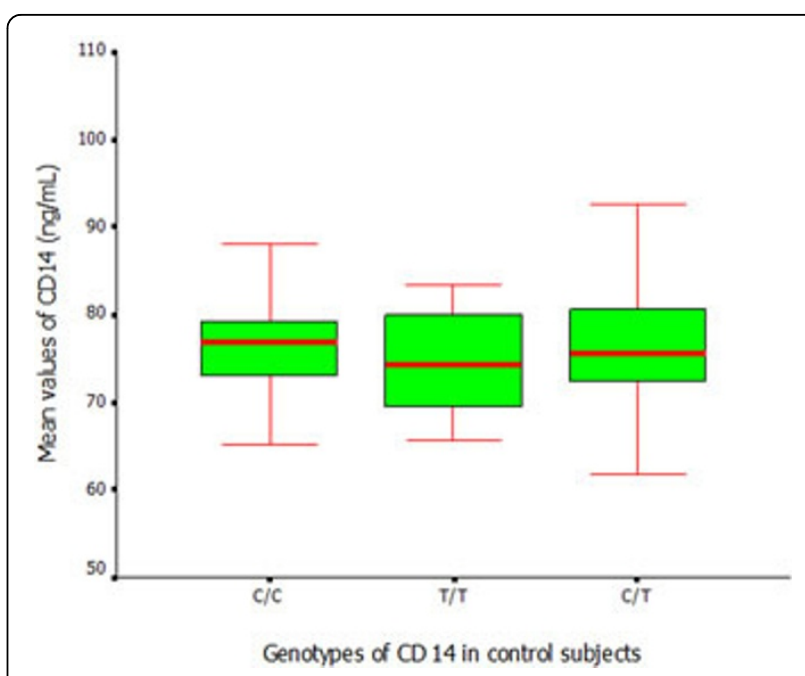

Figure 8 ELISA assay of CD14 (Mean \pm SD) applied to measure the serum levels in control subjects with different CD14 genotypes.

CD14 along with TLR-4 and MD-2 detects bacterial LPS and causes the release of cytokines and antimicrobial peptides like hBDs. The present study extended to investigate $C D 14$ gene polymorphisms along with antimicrobial peptide polymorphisms. In previous studies, it was proven that there would be increased soluble sCD14 levels in the saliva and serum of patients with periodontal infection $[57,58]$. Currently, CD14 gene polymorphisms are considered as potential diagnostic markers for periodontitis. The results from this study established the detection frequency of $C D 14 \mathrm{~T} / \mathrm{T}$ genotype in periodontitis patients $(43 \%)$ to be significantly greater than periodontally healthy controls $(26 \%)$. It is interesting to note the serum levels of CD14 in the periodontitis group was significantly higher than the levels

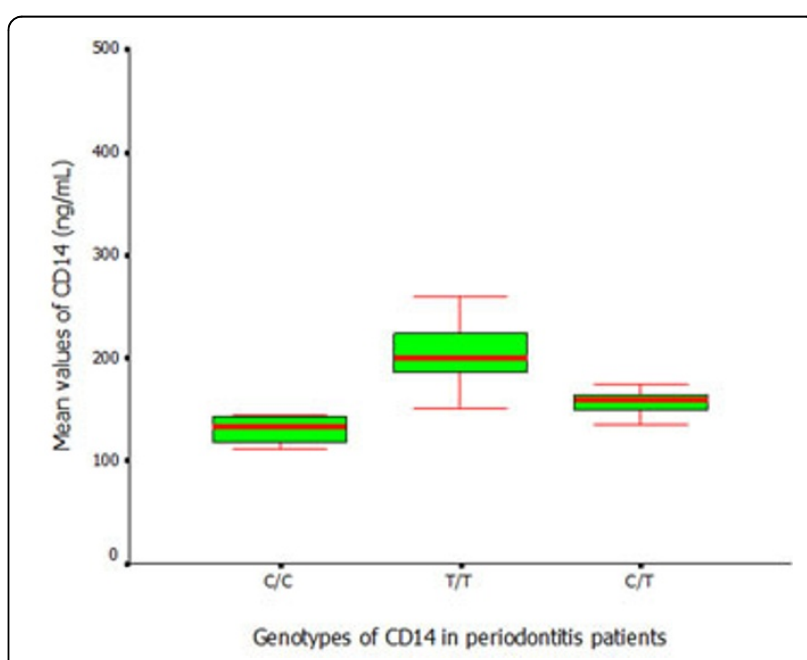

Figure 9 ELISA assay of CD14 (Mean \pm SD) applied to measure the serum levels in periodontitis patients with different CD14 genotypes. 
in the controls. Similarly, periodontal patients with the same genotypes displayed higher levels of CD14 than their healthy subjects. Even within the periodontitis group, subjects with the $\mathrm{T} / \mathrm{T}$ genotype exhibited higher levels of CD14 than subjects with $\mathrm{C} / \mathrm{C}$ or $\mathrm{C} / \mathrm{T}$ genotypes. The current findings on an increased detection frequency of $\mathrm{T} / \mathrm{T}$ genotype in parallel with an increased serum level of CD14 protein is consistent with other studies on genetic polymorphisms of $C D 14$ gene where the $\mathrm{T} / \mathrm{T}$ genotype is also shown to be more frequent in severe periodontitis. The present study supports the notion that a T/T genotype at the -159 position of the $C D 14$ gene is associated with chronic periodontitis. It is estimated that individuals with the $\mathrm{T} / \mathrm{T}$ genotype are at twice a greater risk for moderate to severe periodontitis than people with $\mathrm{C} / \mathrm{C}$ and $\mathrm{C} / \mathrm{T}$ genotypes.

\section{Conclusions}

The current study demonstrates that patients with moderate to severe chronic periodontitis present more commonly with the $-1654 \mathrm{~A} / \mathrm{A}$ genotype on the DEFB1 gene and the $-159 \mathrm{~T} / \mathrm{T}$ genotype on the $C D 14$ gene, in parallel with increased serum levels of hBD-2 and soluble CD14. Within the limitations of the study, the present findings suggest that $D E F B 1$ and $C D 14$ gene polymorphisms are significantly associated with chronic periodontitis and could possibly be potential markers for assessment of risk for periodontal disease. Further investigation is warranted to elaborate on the diagnostic values of these potential markers in clinical practice.

\footnotetext{
Acknowledgements

The authors thank Dr. Eva Loo Kwok Ying of Keenlink Dental Clinic, Hong Kong for performing pre-study screening for our subjects.

This article has been published as part of Journal of Translational Medicine Volume 10 Supplement 1, 2012: Selected articles from the Organisation for Oncology and Translational Research (OOTR) 7th Annual Conference. The full contents of the supplement are available online at http://www.translationalmedicine.com/supplements/10/S1.
}

\section{Author details \\ ${ }^{1}$ UNIMED Medical Institute, Hong Kong SAR. ${ }^{2}$ School of Chinese Medicine, Li Ka Shing Faculty of Medicine, The University of Hong Kong, Pokfulam, Hong Kong SAR. ${ }^{3}$ Department of Stomatology, Sichuan Academy of Medical Sciences \& Sichuan Provincial People's Hospital, No.32, Section 2, 1st Ring Road (West), Chengdu, Sichuan Province, PRC. ${ }^{4}$ Stomatological Hospital of Guangzhou Medical College, Guangzhou, PRC. ${ }^{5}$ State Key Laboratory for Oral Diseases and Department of Prosthodontics, West China Hospital of Stomatology, Sichuan University, Sichuan, PRC. ${ }^{6}$ Jin Hua Dentistry, Chengdu, 610041, Sichuan, PRC. ${ }^{7}$ Keenlink Dental Clinic, Hong Kong SAR.}

\section{Authors' contributions}

WTYL conducted the research, performed data collection and data analysis, and participated in manuscript writing. $Y Y$ and $C F, J L$ and $Y T$ conducted the clinical examination and performed data collection. LB performed data collection and data analysis. MW supervised clinical examination and participated in manuscript planning. $\mathrm{HL}$ performed data analysis and participated manuscript writing. MNBC conducted the clinical examination and participated in manuscript writing. LWCC participated in manuscript planning and writing. Dr. Liu Qing was responsible for data collection. All authors read and approved the final manuscript.

\section{Competing interests}

We declare that we have no financial and personal relationships with other people or organizations that can inappropriately influence our work. There is no professional or other personal interest of any nature or kind in any product, service and/or company that could be construed as influencing the position presented in, the article entitled, "Clinical application of human $\beta$ defensin and CD14 gene polymorphism in evaluating the status of chronic Inflammation".

Published: 19 September 2012

\section{References}

1. Al-Ghamdi HS, Anil S: Serum antibody levels in smoker and non-smoker Saudi subjects with chronic periodontitis. J Periodontol 2007, 78:1043-1050.

2. Mullally BH, Coulter WA, Hutchinson JD, Clarke HA: Current oral contraceptive status and periodontitis in young adults. J Periodontol 2007, 78:1031-6.

3. Philstrom BL, Michalowicz BS, Johnson NW: Periodontal diseases. Lancet 2005, 366:1809-20

4. Thiha K, Takeuchi $Y$, Umeda M, Huang Y, Ohnishi M, Ishikawa I: Identification of periodontopathic bacteria in gingival tissue of Japanese periodontitis patients. Oral Microbiol Immunol 2007, 22:201-7.

5. Johnson GK, Guthmiller JM: The impact of cigarette smoking on periodontal disease and treatment. Periodontol 2000 2007, 44:178-194.

6. Mealey BL, Ocampo GL: Diabetes mellitus and periodontal disease. Periodontol 2000 2007, 44:127-53.

7. Boyapati L, Wang HL: The role of stress in periodontal disease and wound healing. Periodontol 2000 2007, 44:195-210.

8. Saxer UP, Walter C, Bornstein MM, Klingler K, Ramseier CA: Impact of tobacco use on the periodontium-an update. Part 2: Clinical and radiographic changes in the periodontium and effects on periodontal and implant therapy. Schweiz Monatsschr Zahnmed 2007, 117:153-69.

9. Ritchie CS: Obesity and periodontal disease. Periodontol 20002007 , 44:154-163.

10. Geurs NC: Osteoporosis and periodontal disease. Periodontol 20002007 , 44:29-43.

11. Yoshie H, Kobayashi T, Tai H, Galicia JC: The role of genetic polymorphisms in periodontitis. Periodontol 2000 2007, 43:102-32.

12. Huynh-Ba G, Lang NP, Tonetti MS, Salvi GE: The association of the composite IL-1 genotype with periodontitis progression and/or treatment outcomes: a systematic review. J Clin Periodontol 2007, 34:305-17.

13. Müller HP, Barrieshi-Nusair KM: A combination of alleles 2 of interleukinlL; $-1 \mathrm{~A}(-889)$ and $\mathrm{IL}-1 \mathrm{~B}(+3954)$ is associated with lower gingival bleeding tendency in plaque-induced gingivitis in young adults of Arabic heritage. Clin Oral Investig 2007, 11:297-302.

14. Rausch-Fan X, Ulm C, Jensen-Jarolim E, Schedle A, Boltz-Nitulescu G, Rausch WD, Matejka M: Interleukin-1beta-induced prostaglandin E2 production by human gingival fibroblasts is upregulated by glycine. J Periodontol 2005, 76:1182-8.

15. Sumer AP, Kara N, Keles GC, Gunes S, Koprulu H, Bagci H: Association of interleukin-10 gene polymorphisms with severe generalized chronic periodontitis. J Periodontol 2007, 78:493-7.

16. Takahashi K, Azuma T, Motohira H, Kinane DF, Kitetsu S: The potential role of interleukin-17 in the immunopathology of periodontal disease. J Clin Periodontol 2005, 32:369-74.

17. Hannas AR, Pereira JC, Granjeiro JM, Tjäderhane L: The role of matrix metalloproteinases in the oral environment. Acta Odontol Scand 2007, 65:1-13.

18. Li M, Lai Y, Villaruz AE, Cha DJ, Sturdevant DE, Otto M: Gram-positive three-component antimicrobial peptide-sensing system. Proc Natl Acad Sci USA 2007, 104:9469-74.

19. Lu Q, Jin L, Darveau RP, Samaranayake LP: Expression of human betadefensins- 1 and -2 peptides in unresolved chronic periodontitis. J Periodontal Res 2004, 39:221-7. 
20. Linzmeier RM, Ganz T: Human defensin gene copy number polymorphisms: comprehensive analysis of independent variation in alpha- and beta-defensin regions at 8p22-p23. Genomics 2005, 86:423-30.

21. Bensch KW, Raida M, Magert HJ, Schulz-Knappe P, Forssmann WG: hBD-1: a novel beta-defensin from human plasma. FEBS Lett 1995, 368:331-335.

22. Diamond $G$, Bevins CL: ß-Defensins: endogenous antibiotics of the innate host defense response. Clin Immunol Immunopathol 1998, 88:221.

23. Liu L, Wang L, Jia HP, Zhao C, Heng HHQ, Schutte BC, McCray PB Jr, Ganz T: Structure and mapping of the human B-defensin HBD-2 gene and its expression at sites of inflammation. Gene 1998, 222:237.

24. Harder J, Schroder JM: Antimicrobial peptides in human skin. Chem Immunol Allergy 2005, 86:22-41.

25. de Jongh GJ, Zeeuwen PL, Kucharekova M, Pfundt R: High expression levels of keratinocyte antimicrobial proteins in psoriasis compared with atopic dermatitis. J Invest Dermatol 2005, 125:1163-1173.

26. Jansen PAM, Rodijk-Olthuis D, Hollox EJ, Kamsteeg M, Tjabringa GS, de Jong GJ: $\beta$-Defensin-2 Protein Is a Serum Biomarker for Disease Activity in Psoriasis and Reaches Biologically Relevant Concentrations in Lesional Skin. PLOS ONE 2009, 4:e4725.

27. Cole AM, Dewan P, Ganz T: Innate antimicrobial activity of nasal secretions. Infect Immun 1999, 67:3267-3275.

28. Krisanaprakornkit S, Kimball JR, Weinberg A, Darveau RP, Bainbridge BW, Dale BA: Inducible expression of human beta-defensin 2 by fusobacterium nucleatum in oral epithelial cells: multiple signaling pathways and role of commensal bacteria in innate immunity and the epithelial barrier. Infect Immun 2000, 68:2907-2915.

29. Dale BA, Kimball JR, Krisanaprakornkit S, Roberts F, Robinovitch M, O'Neal R, Valore EV, Ganz T, Anderson GM, Weinberg A: Localized antimicrobial peptide expression in human gingiva. J Periodontal Res 2001, 36:285-94.

30. Singh PK, Jia HP, Wiles K, Hesselberth J, Liu L, Conway BA, Greenberg EP, Valore EV, Welsh MJ, Ganz T, Tack BF, McCray PB Jr: Production of betadefensins by human airway epithelia. Proc Natl Acad Sci U S A 1998, 95:14961-6.

31. Paulsen FP, Pufe T, Schaudig U, Held-Feindt J, Lehmann J, Schröder JM, Tillmann BN: Detection of natural peptide antibiotics in human nasolacrimal ducts. Invest Ophthalmol Vis Sci 2001, 42:2157-63.

32. Paulsen RJ, Tighe PJ, Dua HS: Antimicrobial defensin peptides of the human ocular surface. Br J Ophthalmol 1999, 83:737-741.

33. O'Neil DA, Porter EM, Elewaut D, Anderson GM, Eckmann L, Ganz T, Kagnoff MF: Expression and regulation of the human betadefensins hBD1 and hBD-2 in intestinal epithelium. J Immunol 1999, 163:6718-6724.

34. Boniotto M, Hazbon MH, Jordan WJ, Lennon GP, Eskdale J, Alland D, Gallagher G: Novel hairpin-shaped primer assay to study the association of the -44 single-nucleotide polymorphism of the DEFB1 gene with early-onset periodontal disease. Clin Diagn Lab Immunol 2004, 11:766-9.

35. Matsushita I, Hasegawa K, Nakata K, Yasuda K, Tokunaga K, Keicho N: Genetic variants of human beta-defensin-1 and chronic obstructive pulmonary disease. Biochem Biophys Res Commun 2002, 291:17-22.

36. Prado-Montes de Oca E, García-Vargas A, Lozano-Inocencio R, GallegosArreola MP, Sandoval-Ramírez L, Dávalos-Rodríguez NO, Figuera LE: Association of beta-defensin 1 single nucleotide polymorphisms with atopic dermatitis. Int Arch Allergy Immunol 2007, 142:211-8.

37. Wright SD, Ramos RA, Tobias PS, Ulevitch RJ, Mathison JC: CD14, a receptor for complexes of lipopolysaccharideLPS) and LPS binding protein. Science 1990, 249:1431-3.

38. Pugin J, Heumann ID, Tomasz A, Kravchenko W, Akamatsu Y, Nishijima M, Glauser MP, Tobias PS, Ulevitch RJ: CD14 is a pattern recognition receptor. Immunity 1994, 1:509-16.

39. Ulevitch RJ, Tobias PS: Receptor-dependent mechanisms of cell stimulation by bacterial endotoxin. Annu Rev Immunol 1995, 13:437-57.

40. Holla LI, Buckova D, Fassmann A, Halabala T, Vasku A, Vacha J: Promoter polymorphisms in the CD14 receptor gene and their potential association with the severity of chronic periodontitis. J Med Genet 2002, 39:844-848.

41. Horneff G, Sack U, Kalden JR, Emmrich F, Burmester GR: Reduction of monocyte-macrophage activation markers upon anti-CD4 treatment: decreased levels of IL-1, IL-6, neopterin and soluble CD14 in patients with rheumatoid arthritis. Clin Exp Immunol 1993, 91:207-13.

42. Egerer K, Feist E, Rohr U, Pruss A, Burmester GR, Dorner T: Increased serum soluble CD14, ICAM-1 and E-selectin correlate with disease activity and prognosis in systemic lupus erythematosus. Lupus 2000, 9:614-21.
43. Hoheisel G, Zheng L, Teschler H, Striz I, Costabel U: Increased soluble CD14 levels in BAL fluid in pulmonary tuberculosis. Chest 1995, 108:1614-6.

44. Unkelbach K, Gardemann A, Kostrzewa M, Philipp M, Tillmanns H, Haberbosch W: A new promoter polymorphism in the gene of lipopolysaccharide receptor CD14 is associated with expired myocardial infarction in patients with low atherosclerotic risk profile. Arterioscler Thromb Vasc Biol 1999, 19:932-8.

45. Rosas-Taraco AG, Revol A, Salinas-Carmona MC, Rendon A, Caballero-Olin G, Arce-Mendoza AY: CD14 C(-159) T polymorphism is a risk factor for development of pulmonary tuberculosis. J Infect Dis 2007, 196:1698-706.

46. Lu Q, Darveau RP, Samaranayake LP, Wang CY, Jin L: Differential modulation of human b-defensins expression in human gingival epithelia by Porphyromonas gingivalis lipopolysaccharide with tetraand penta-acylated lipid A structures. Innate Immunity 2009, 15:325-335.

47. Lemeshow S, Hosmer DW, Klar J, Lwanga SK: Adequacy of sample size in health studies Published on behalf of the World Health Organization. Wiley 1990, 1-293.

48. Machin D, Campbell MJ, Tan SB, Tan SH: Sample Size Tables for Clinical Studies. Wiley-Blackwell, 3rd 2009.

49. Armitage GC: Development of a classification system for periodontal diseases and conditions. Ann Periodontol 1999, 4:1-6.

50. Kedda MA, Lose F, Duffy D, Bell E, Thompson PJ, Upham J: The CD14 C 159T polymorphism is not associated with asthma or asthma severity in an Australian adult population. Thorax 2005, 60:211-4

51. Jurevic RJ, Bai M, Chadwick RB, White TC, Dale BA: Single-nucleotide polymorphismsSNPs; in human beta-defensin 1: high-throughput SNP assays and association with Candida carriage in type I diabetics and nondiabetic controls. J Clin Microbiol 2003, 41:90-6.

52. Leung TF, Li CY, Liu EK, Tang NL, Chan IH, Yung E, Wong GW, Lam CW: Asthma and atopy are associated with DEFB1 polymorphisms in Chinese children. Genes Immun 2006, 7:59-64.

53. Segat L, Milanese $M$, Boniotto $M$, Crovella S, Bernardon M, Costantini M, Alberico S: Italian Group SIGO HIV in Obstetrics and Gynecology. DEFB-1 genetic polymorphism screening in HIV-1 positive pregnant women and their children. J Matern Fetal Neonatal Med 2006, 19:13-6.

54. Mittal RD, Mishra DK, Mandhani A: Evaluating polymorphic status of glutathione-S-transferase genes in blood and tissue samples of prostate cancer patients. Asian Pac J Cancer Prev 2006, 7:444-6.

55. Schaefer AS, Richter GM, Nothnagel M, Laine $M L$, Rühling A, Schäfer $C$, Cordes N, Noack B, Folwaczny M, Glas J, Dörfer C, Dommisch H, GroessnerSchreiber B, Jepsen S, Loos BG, Schreiber S: A 3' UTR transition within DEFB1 is associated with chronic and aggressive periodontitis. Genes Immun 2010, 11:45-54.

56. Eilertsen $\mathrm{KE}$, Olsen JO, Brox J, ØSterud B: Association of the $-159 \mathrm{C} \rightarrow \mathrm{T}$ polymorphism in the CD14 promoter with variations in serum lipoproteins in healthy subjects. Blood Coagul Fibrinolysis 2003, 14:663-70

57. Hayashi J, Masaka T, Ishikawa I: Increased levels of soluble CD14 in sera of periodontitis patients. Infect Immun 1999, 67:417-420.

58. Raunio T, Knuuttila M, Karttunen R, Vainio O, Tervonen T: Serum sCD14, polymorphism of CD14(-260) and periodontal infection. Oral Dis 2009, 15:484-9.

59. Yamazaki K, Ueki-Maruyama K, Oda T, Tabeta K, Shimada Y, Tai H, Nakajima T, Yoshie H, Herawati D, Seymour GJ: Single-nucleotide polymorphism in the CD14 promoter and periodontal disease expression in a Japanese population. J Dent Res 2003, 82:612-616.

doi:10.1186/1479-5876-10-S1-S9

Cite this article as: Loo et al: Clinical application of human $\beta$-defensin and CD14 gene polymorphism in evaluating the status of chronic inflammation. Journal of Translational Medicine 2012 10(Suppl 1):S9. 